\title{
Id proteins: emerging roles in CNS disease and targets for modifying neural stemcell behavior
}

\author{
Yu-Hsuan Chu ${ }^{1,2} \cdot$ Jia-di Lin ${ }^{1,2} \cdot$ Suvra Nath ${ }^{1,2} \cdot$ Christian Schachtrup ${ }^{1,3}$ (1)
}

Received: 12 April 2021 / Accepted: 18 June 2021 / Published online: 24 July 2021

(c) The Author(s) 2021

\begin{abstract}
Neural stem/progenitor cells (NSPCs) are found in the adult brain and spinal cord, and endogenous or transplanted NSPCs contribute to repair processes and regulate immune responses in the CNS. However, the molecular mechanisms of NSPC survival and integration as well as their fate determination and functionality are still poorly understood. Inhibitor of DNA binding (Id) proteins are increasingly recognized as key determinants of NSPC fate specification. Id proteins act by antagonizing the DNA-binding activity of basic helix-loop-helix (bHLH) transcription factors, and the balance of Id and bHLH proteins determines cell fate decisions in numerous cell types and developmental stages. Id proteins are central in responses to environmental changes, as they occur in CNS injury and disease, and cellular responses in adult NSPCs implicate Id proteins as prime candidates for manipulating stemcell behavior. Here, we outline recent advances in understanding Id protein pleiotropic functions in CNS diseases and propose an integrated view of Id proteins and their promise as potential targets in modifying stemcell behavior to ameliorate CNS disease.
\end{abstract}

Keywords Helix-loop-helix transcription factor $\cdot$ Extracellular matrix $\cdot$ Fibrinogen $\cdot$ Multiple sclerosis $\cdot$ Small molecule inhibitors

\section{Introduction}

Neurological diseases and injuries to the adult mammalian central nervous system (CNS) often lead to permanent cell loss and functional impairment because the CNS has only a limited regeneration capacity. Therapeutic strategies based on neural stem/progenitor cells (NSPCs) are of great interest for promoting CNS regeneration. These approaches work by activating the tissue-resident stemcell reservoir or providing exogenous NSPCs as an alternative source (Assinck et al. 2017; Fischer et al. 2020; Llorens-Bobadilla et al. 2020; Lu et al. 2012; Peruzzotti-Jametti et al. 2018; Pluchino et al. 2020). The contributions of NSPCs to cell replacement and

Christian Schachtrup

christian.schachtrup@anat.uni-freiburg.de

1 Institute of Anatomy and Cell Biology, Faculty of Medicine, University of Freiburg, Freiburg, Germany

2 Faculty of Biology, University of Freiburg, Freiburg, Germany

3 Center for Basics in NeuroModulation (NeuroModulBasics), Faculty of Medicine, University of Freiburg, Freiburg, Germany their ability to mediate immune responses are well recognized. However, the molecular mechanisms that regulate NSPC survival, cell-fate determination, and functional integration into the injured tissue under pathological conditions are poorly understood.

A comprehensive understanding of these regulatory paths would be valuable for harnessing both endogenous and transplanted NSPCs for a more effective therapeutic repair. A fine-tuned cellular and molecular environment of NSPCs is instrumental for maintaining and directing their differentiation (Chaker et al. 2016; Ihrie and Alvarez-Buylla 2011; Schildge et al. 2014). Pathological states alter the finely tuned NSPC environment by disrupting signaling pathways and transcriptional networks resulting in misguided NSPC fate and functionality and thus limiting the NSPC potential for CNS regeneration.

Recently, our laboratory identified inhibitor of DNA (Id) proteins as a link between the altered cell environment and the ability of transcription factors (TFs) in NSPCs to regulate NSPC differentiation and functionality. We showed that blood-derived fibrinogen is enriched in the NSPC environment after CNS injury (e.g., traumatic brain injury) or neurological disease (e.g., multiple sclerosis 
(MS)). Mechanistically, fibrinogen activates bone morphogenetic protein (BMP) type I receptor (BMPR I) signaling and triggers Id expression in NSPCs and oligodendrocyte progenitor cells (OPCs), inducing astrogliogenesis and inhibiting oligodendrocyte differentiation, respectively (Lin et al. 2021; Petersen et al. 2017; Pous et al. 2020) (Fig. 1). Thus, we found that, as the stemcell microenvironment changed during disease states, the BMPR I-Id axis responds rapidly to orchestrate NSPC behavior. Here, we provide an overview on the biological properties of Id

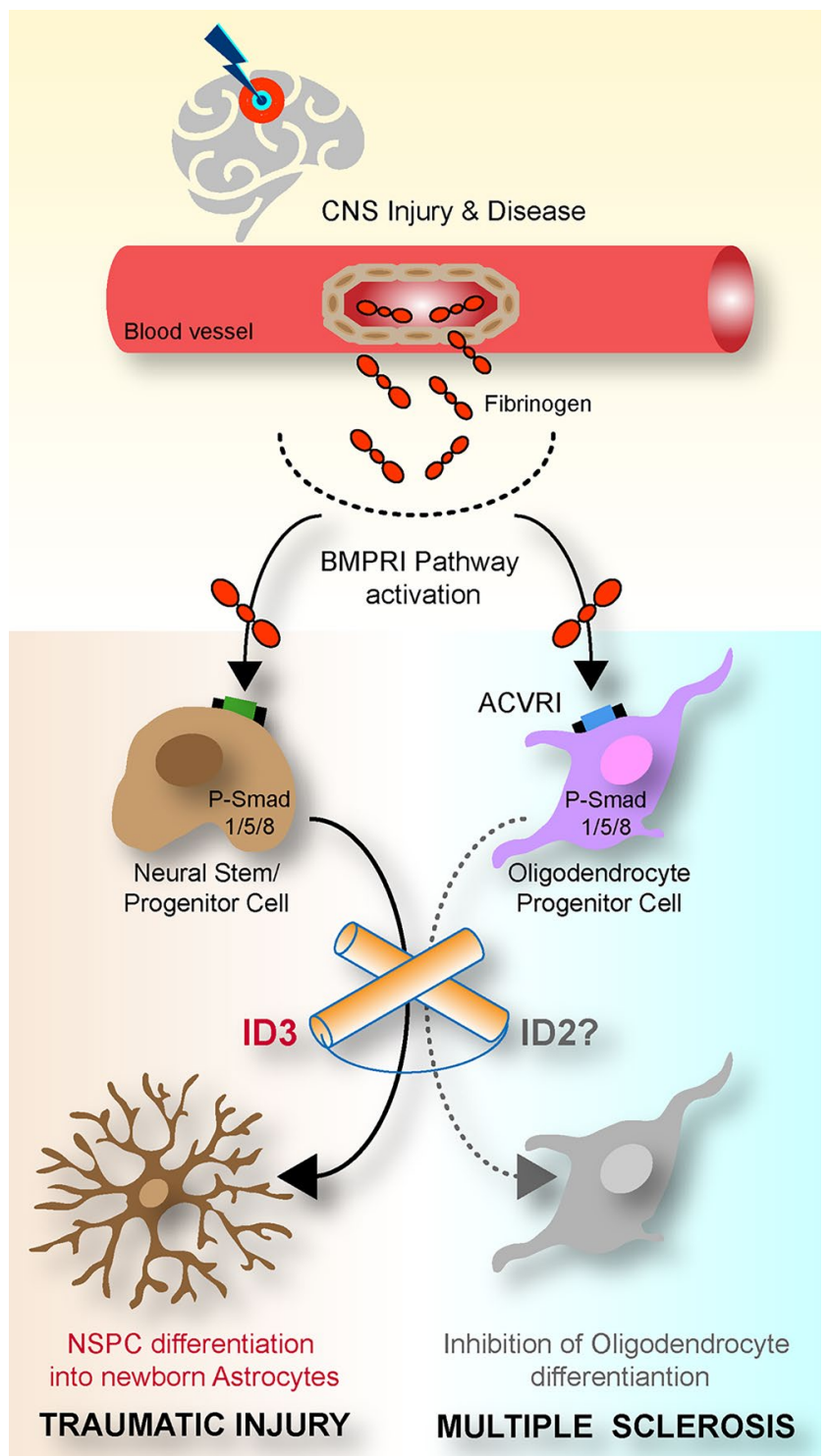

Fig. 1 Id proteins regulate NSPC and oligodendrocyte progenitorcell fate in CNS injury and disease. After traumatic injury (left) or multiple sclerosis (right) with BBB opening or vascular rupture, blood-derived fibrinogen activates BMP signaling. As a result, Id upregulation in NSPCs and oligodendrocyte progenitor cells induce astrogliogenesis and inhibit oligodendrocyte differentiation, respectively proteins and discuss the current knowledge about the Id function in CNS disease and how this knowledge might be applied to modify NSPC fate and functions that promote CNS repair.

\section{Id structure and interaction partner}

Id proteins (Id1-Id4) belong to the helix-loop-helix (HLH) protein family (Fig. 2a) (Murre 2019). Each of them contains a highly conserved HLH domain, but lacks a basic region for DNA binding (Fig. 2b). Thus, the crucial biochemical attribute of each Id family member is their antagonizing effect on basic (b) HLH TFs that orchestrate cellfate determination (Dennis et al. 2019). The bHLH domain is tripartite and comprises a basic DNA-binding region and two amphipathic $\alpha$-helices connected by a loop domain. Binding occurs through the basic region adjacent to the HLH motif, and they bind to target genes with a distinct DNA segment, named E-box site, that contains a signature core of six nucleotides: CANNTG. Lineage-restricted class II bHLH TFs, including the neural-specific bHLH TFs Ascl, NeuroD, Ngn1/2, and Olig1/2, form heterodimers through the HLH dimerization region with ubiquitously expressed class I (E protein) bHLH proteins (e.g., E2A/TCF3, E2-2/TCF4, and HEB/TCF12) (Bertrand et al. 2002). The primary binding partners of Id proteins are class I bHLH proteins (E proteins) (Langlands et al. 1997). In the presence of excessive Id proteins, Id-bHLH rather than bHLH-bHLH association prevails, and because the Id proteins do not contain a basic region, the Id-bHLH heterodimer is unable to bind to DNA, and bHLH-directed transcription is blocked (Fig. 2c) (Norton et al. 1998; Sun et al. 1991).

The four Id proteins are characterized by an HLH motif of 41 residues and by different long $\mathrm{N}$ - and C-terminal tails. Although the HLH domain of the Id proteins is involved in most of their protein-protein interaction events, additional motifs located in their $\mathrm{N}$-terminal and $\mathrm{C}$-terminal regions are required for the recognition of diverse protein partners. The ability of the Id proteins to interact with structurally different proteins is likely to arise from their conformational flexibility. Indeed, these proteins contain intrinsically disordered regions (Beisswenger and Cabrele 2014; Colombo and Cabrele 2006; Kiewitz and Cabrele 2005; Linding et al. 2003; Obradovic et al. 2005) that, in the case of the HLH region, undergo folding upon self- or heteroassociation, while the $\mathrm{N}$-terminal and $\mathrm{C}$-terminal regions maintain a high degree of flexibility (Beisswenger et al. 2010; Eletsky et al. 2011; Kiewitz et al. 2008; Svobodova and Cabrele 2006; Wong et al. 2012). While the identity between the HLH regions is very high for the four Id proteins, their other parts are not conserved (Kiewitz and Cabrele 2005; Roschger 
a

\begin{tabular}{|l|c|l|l|}
\hline $\begin{array}{l}\text { HLH } \\
\text { protein } \\
\text { class }\end{array}$ & $\begin{array}{l}\text { HGNC } \\
\text { approved } \\
\text { gene symbol }\end{array}$ & $\begin{array}{l}\text { Alternative } \\
\text { names }\end{array}$ & $\begin{array}{l}\text { Protein } \\
\text { names }\end{array}$ \\
\hline I & TCF4 & $\begin{array}{l}\text { E2-2 } \\
\text { ITFA } \\
\text { SEF2 } \\
\text { bHLHb21 }\end{array}$ & TCF4 \\
\hline I & TCF3 & $\begin{array}{l}\text { E3A } \\
\text { ITF1 } \\
\text { bHLHb21 }\end{array}$ & $\begin{array}{l}\text { E2A } \\
\text { ECF3 }\end{array}$ \\
\hline I & TCF12 & $\begin{array}{l}\text { HEB } \\
\text { HTF4 } \\
\text { bHLHb20 }\end{array}$ & TCF12 \\
\hline $\mathrm{V}$ & ID1 & bHLHb24 & ID1 \\
\hline $\mathrm{V}$ & ID2 & $\begin{array}{l}\text { GIG8 } \\
\text { ID2A }\end{array}$ & ID2 \\
& & $\begin{array}{l}\text { ID2H } \\
\text { bHLHb26 }\end{array}$ & \\
\hline $\mathrm{V}$ & ID3 & $\begin{array}{l}\text { HEIR-1 } \\
\text { bHLHb25 }\end{array}$ & ID3 \\
\hline $\mathrm{V}$ & ID4 & $\begin{array}{l}\text { IDB4 } \\
\text { bHLHb27 }\end{array}$ & ID4 \\
\hline
\end{tabular}

C

Ubiquitous bHLH
TCF3
(E12/E47)
TCF4
TCF12

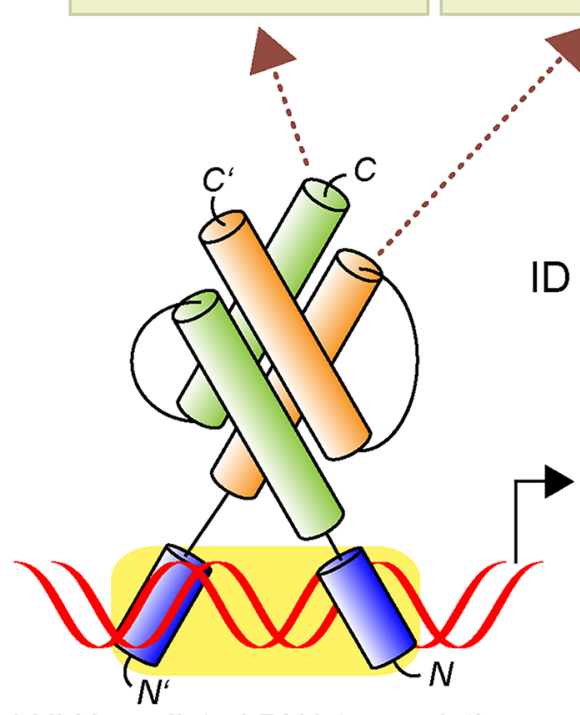

bHLH-mediated DNA transcription

$$
\begin{array}{|l|l|}
\hline \text { E-BOX } & \text { C-A-N-N-T-G } \\
\hline
\end{array}
$$

Fig. 2 Id protein control of NSPC self-renewal and differentiation. a Class I and class V proteins of the HLH transcription factor family. b NMR structure of Id3 (UniProtKB). c Ubiquitously expressed bHLH $\mathrm{E}$ proteins build heterodimers with tissue-specific bHLH proteins, which results in DNA binding at specific DNA sequences (E-box in
$\mathrm{Ngn} 1 / 2$

Olig $1 / 2$

\section{protein}

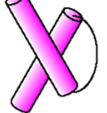

b

\section{ID3 NMR structure}

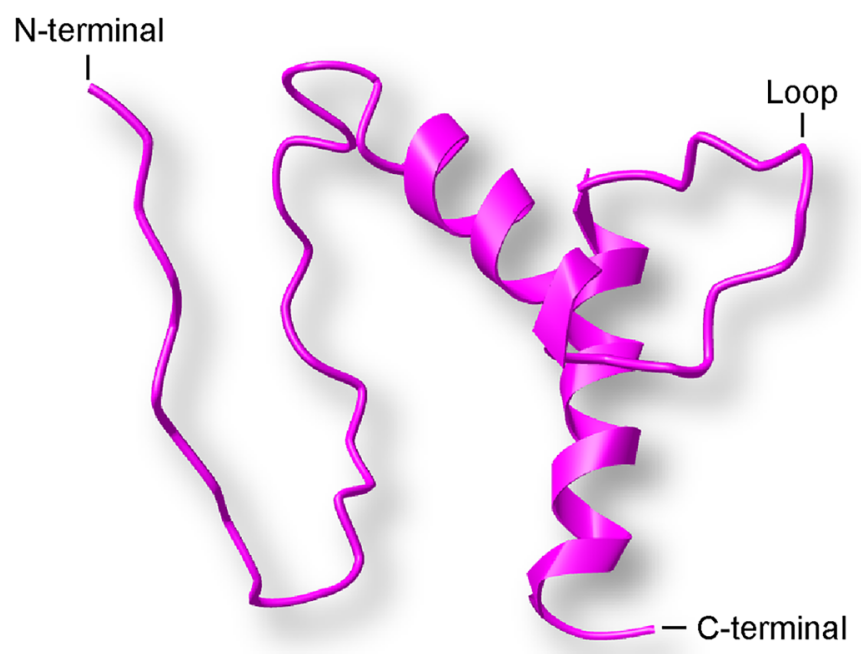

Neural Stem Cell self-renewal

\& fate determination
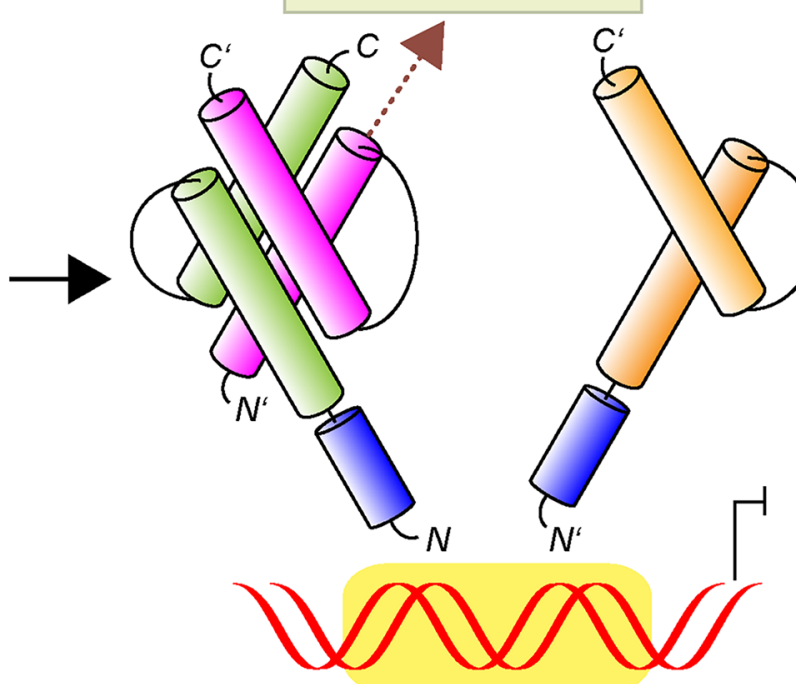

ID-inhibited DNA transcription

$$
\text { E-BOX } \mathrm{C}-\mathrm{A}-\mathrm{N}-\mathrm{N}-\mathrm{T}-\mathrm{G}
$$

yellow) and DNA-transcription activation. Dimers of E proteins and Id proteins cannot bind DNA because the Id subunit lacks a DNA binding region, which leads to inhibition of DNA-transcription activation 
and Cabrele 2017), and these sequence differences explain the differences in protein structure and stability, subcellular localization, binding partner, and subsequent functionality between Ids. For example, a destruction box motif (D-box) is conserved in Id1, Id2, and Id4, but not in Id3 (Lasorella, et al. 2006); but a nuclear export signal (NES) is only found in Id2 (Karaya, et al. 2005) and Id1 (Makita et al. 2006), suggesting differential protein degradation and regulation of the subcellular distribution of Ids. For example, Id 2 is the only Id protein to recognize the retinoblastoma protein, presumably by interactions between the HLH region and the B-box of the cyclin fold (Iavarone et al. 1994; Lasorella et al. 2000). Furthermore, the potency order of Id 2 binding to the ubiquitous TFs is as follows: E47 > E12, E2-2 > HEB (Langlands et al. 1997). In contrast, Id1 and Id 3 bind all the E proteins with similar affinity, with the exception of HEB, which is bound less strongly.

Id proteins also interact with class II bHLH proteins (e.g., OLIG1/2) and non-bHLH TFs (e.g., ternary complex factors (TCFs)), which are a subfamily of ETS-domain TFs (Yates et al. 1999) and paired-domain transcription factor (PAX) family members (Roberts et al. 2001). Thus, in spite of sharing the highly conserved HLH domain, the differences in structure and binding partner preference suggest a broad facet of functional diversity for each Id family member. However, differences in Id-specific binding partners and functionality in CNS cells and especially in endogenous and transplanted NSPCs are poorly understood and need to be further explored for modifying stemcell behavior for a more effective therapeutic repair to ameliorate CNS diseases.

\section{Regulation of Id abundance}

Id gene expression and protein abundance are regulated by a wide range of growth factor and cytokine signaling cascades, as well as by post-translational modifications and degradation. Yet, factors that regulate levels of Id proteins in NSPCs in homeostasis and after CNS injury and disease are just emerging.

Growth factors In the CNS, Id gene expression is regulated by the TGF- $\beta$ superfamily (Fig. 3) (Hollnagel et al. 1999; Kang et al. 2003; Miyazono and Miyazawa 2002). While TGF- $\beta$ signaling has opposing effects on Id abundance, BMP signaling robustly increases Id expression in various CNS cell types. We showed that TGF- $\beta$ represses Id 3 transcription and consequently Id 3 protein abundance in adult subventricular zone (SVZ)-derived NSPCs (Bohrer et al. 2015). However, studies in epithelial cells outside the CNS revealed a potential general mechanism of TGF- $\beta$-regulated $I d$ expression, where the $I d l$ expression is transiently induced by TGF- $\beta$ in a Smad3/4 complexmediated pathway (Liang et al. 2009), but long-term TGF- $\beta$ stimulation led to the synthesis of activating transcription factor 3 (ATF3), which interacts with Smad3 and directs the binding of the Smad complex to the CRE/ATF consensus sequence within the IdI promoter, mediating the transcriptional repression of IdI (Kang et al. 2003). This mechanism has not been reported in CNS cells. The binding of BMP ligands to their corresponding receptors triggers intracellular Smad signaling, mediated by Smad1, a receptor-regulated Smad (R-Smad), and Smad4, a common partner Smad (Co-Smad). The nuclear translocation of the Smad1/Smad4 complex activates the expression of Id genes by directly binding to a Smad-binding element (SBE) in their transcription regulatory region (Fig. 3) (Katagiri et al. 2002; Nakahiro et al. 2010). The shortrange morphogen BMP is ideally suited to fine-tune stemcell behavior and influencing all stages of neurogenesis. Thus, as part of BMP downstream targets, Id proteins are central in transiting these signals into cellular responses in NSPCs.

In embryonic stem (ES) cells, BMP-triggered Id expression is critical for maintenance of ES cell self-renewal (Hollnagel et al. 1999) (Romero-Lanman et al. 2012; Ying et al. 2003), and BMP-induced Id expression in neural progenitor cells alters the developmental pathway of fetal mouse brain cells from neurogenesis to astrogliogenesis (Nakashima et al. 2001). In the adult neurogenic niche, BMP signaling is finely tuned to support long-term neurogenesis in the subgranular zone and SVZ (Bonaguidi et al. 2008; Mira et al. 2010; Nam and Benezra 2009). Our laboratory showed that, after cortical injury, elevated BMP-2 levels in the adult SVZ stem-cell niche induced rapid and drastic increases in Id 3 expression in NSPCs. Consequently, NSPCs with elevated Id3 expression levels preferentially differentiated into SVZ-derived newborn astrocytes (Bohrer et al. 2015).

Recently, we identified the blood-derived coagulation factor fibrinogen as a novel inducer of Id expression in adult SVZ and hippocampal NSPCs. Fibrinogen is enriched in the SVZ stemcell niche environment upon cortical injury due to a leaky stemcell niche vasculature. Fibrinogen deposited in the SVZ stemcell niche environment then induces BMP type I receptor localization to lipid rafts to activate BMP signaling via its integrin interacting $\alpha \mathrm{C}$ domain (Pous et al. 2020) (Fig. 3). In addition, fibrinogen deposition in MS lesions triggers Id 2 expression in OPCs via the activation of the BMP receptor activin A receptor type I (ACVRI) (Petersen et al. 2017). These findings suggest that vascular pathology with fibrinogen deposition is a general trigger of increased BMP signaling and consequently increased Id abundance that affect glial and neural progenitor cell differentiation (Lin et al. 2021). 


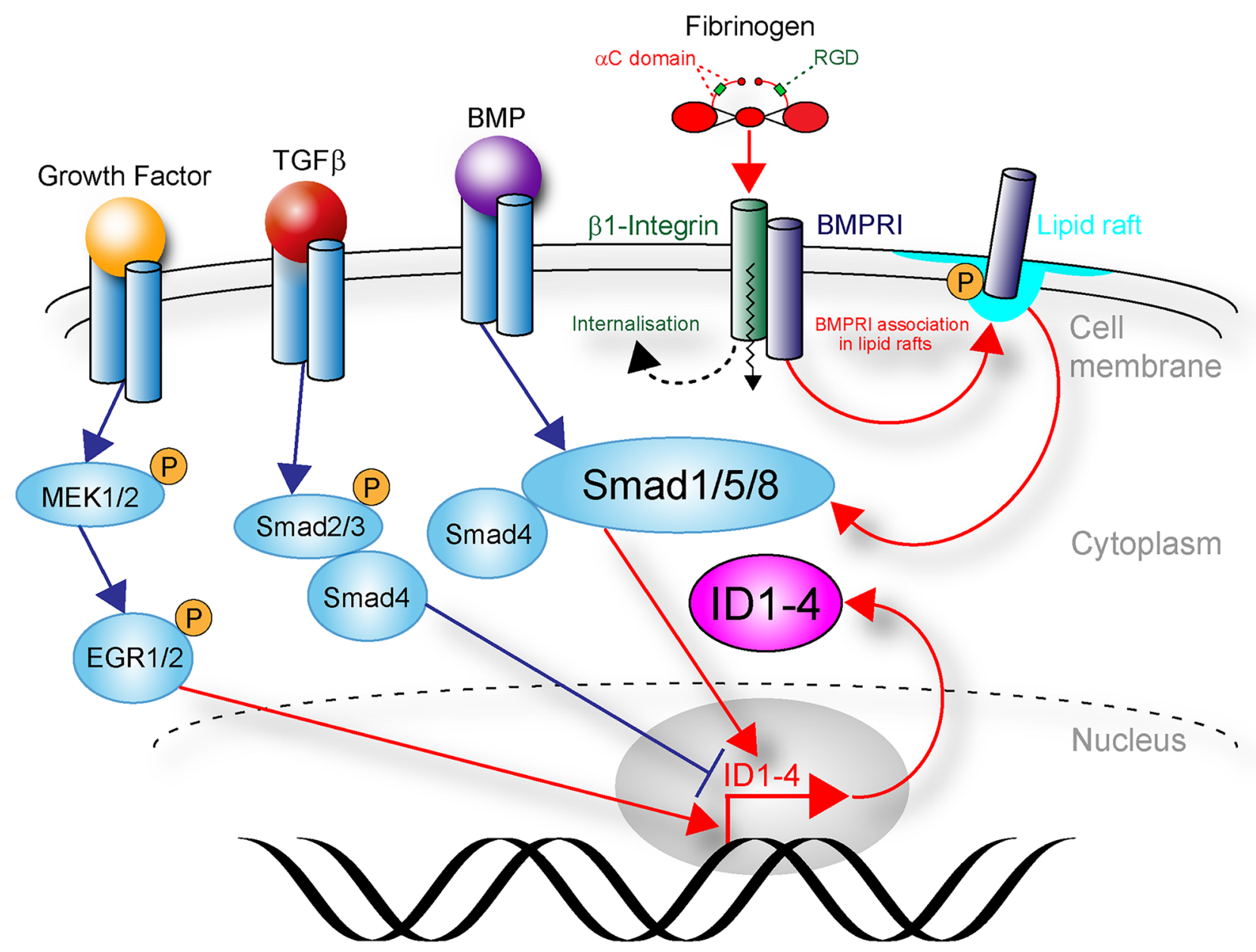

Fig. 3 Regulation of Id expression in CNS disease. Bone morphogenetic protein (BMP) induces BMPR I signaling and induces expression of Id1-4 through SMAD binding to BMP-responsive elements in the promoter of Id genes. Fibrinogen (coagulation factor I) induces Id expression via BMPR I signaling activation. Fibrinogen via its integrin interacting $\alpha \mathrm{C}$ domain induces $\mathrm{BMP}$ type I receptor localization to lipid rafts to activate BMP signaling. Transforming growth factor- $\beta$ (TGF- $\beta$ ) represses expression of Ids. Receptor tyrosine kinases (such as epidermal growth factor receptor, EGFR and fibroblast growth factor receptor, FGFR), converge on MEK-ERK to activate Id gene transcription via the early growth response (EGR) transcription factor
The stemcell niche environment is rich in other growth factors, such as fibroblast growth factor-2 (FGF-2) and epidermal growth factor (EGF), that induce $I d$ expression through the ERK-MEK pathway in cancer cells by direct binding of early growth responsive protein 1 (Egr-1) to the $I d$ promoter (Borlak et al. 2005; Passiatore et al. 2011; Tournay and Benezra 1996). However, the role of FGF-2 and EGF in $I d$ gene regulation in CNS cells and, in particular, NSPCs is not yet established.

Cytokines Cytokines regulate Id protein levels in immune cells. In hematopoietic stem cells (HSCs), Id abundance is regulated by various cytokines (e.g., IL-3, IL-6, and GMCSF) and directs myeloid vs. lymphoid/erythroid cell fate and macrophage vs. neutrophil maturation (Cochrane et al.
2009; Leeanansaksiri et al. 2005; Maeda et al. 2009). Here, the mode of action is activation of C/EBP $\beta$ and STAT transcription factors, both of which bind to the enhancer element at the 3' terminus of Id genes (Karaya et al. 2005; Saisanit and Sun 1997; Xu et al. 2003). A role of cytokines in the regulation of $I d$ expression in CNS cells and, in particular, NSPCs has not yet been reported.

MicroRNAs Further regulatory modules directly targeting Id expression are microRNAs (miRNAs), such as miR-181a, miR-9, and miR-103 (Amado et al. 2020; Annibali et al. 2012), adding another level to Id regulation. However, regulation of Id expression by microRNAs has been examined mainly in cancer cells. Recently, ablation of the miRNA-1792 cluster in neural stem cells was found to diminish adult 
hippocampal neurogenesis and cognitive function, and the miR-17-92 cluster may target the cytoskeleton-associated protein Enigma homolog 1 and its downstream transcription factor Id 1 (Pan et al. 2019). However, involvement of microRNAs in the direct control of Id protein levels in NSPCs under physiological and pathological conditions is unknown.

Id protein regulation Id proteins are short-lived. Their halflives are shorter than $20 \mathrm{~min}$, and they are degraded in the $26 \mathrm{~S}$ proteasome-dependent pathway after $\mathrm{N}$-terminal ubiquitination. Ubiquitin-dependent degradation of Id1 and Id3 is mediated by the COP9 signalosome (CSN), whereas Id 1 and Id 3 , but not Id 2 and Id4, bind to the CSN subunit CSN5 (Berse et al. 2004; Bounpheng et al. 1999; Trausch-Azar et al. 2004). Id interaction with bHLH transcription factors, such as E12, E47, and MyoD, increased Id protein stability, suggesting that Id proteins are less susceptible to degradation by the $26 \mathrm{~S}$ proteasome when complexed to a bHLH protein (Lingbeck et al. 2005; Trausch-Azar et al. 2004). Phosphorylation of Id 2 and Id 3 by the cyclin-dependent kinase 2 alters the specificity of the Ids for abrogating both E-box-dependent bHLH homo- or heterodimer complex formation and E-box-dependent reporter gene functions (Deed et al. 1997; Hara et al. 1997) and decreases their stability via the proteasome-dependent degradation (Sullivan et al. 2016). In addition, the C-terminal domains of Id1, Id2, and Id4 contain a destruction box motif (D-box), which is recognized by the anaphase promoting complex/cyclosome (APC/C). Ids interact with the core subunits of APC/C and its co-activator $\mathrm{Cdh} 1$ in primary neurons, targeting Ids for degradation (Lasorella et al. 2006). In NSPCs, regulation of Id protein stability remains unclear. A better understanding of Id-specific protein stability and degradation might inform the development of neural stemcell-specific manipulations of Id family members for future therapeutic approaches.

\section{Id functions in nervous system pathologies}

Id protein functions are very well studied in immune cells and in the cancer field (Lasorella et al. 2014; Murre 2019). Id protein expression in the adult CNS is triggered by various extracellular stimuli during pathological conditions. Knowledge of Id function in mature cells in CNS diseases is limited, but a role for the Id protein family in glial and neural precursor cells in CNS disease is emerging. Here, we highlight Id functions in neurological diseases, such as trauma, stroke, MS, Parkinson's disease (PD), and glioblastoma (GBM).

Trauma and stroke Upregulation of Id genes in a timedependent manner has been described in astrocytes, oligodendrocyte, and neural progenitor cells after spinal cord injury (Tzeng et al. 2001). However, for a long time, a detailed mechanism of action was lacking. Recently, our laboratory described Id functions in adult NSPCs of the SVZ stemcell niche after traumatic brain injury. In the healthy brain, SVZ NSPCs continuously generate newborn neurons that migrate via the rostral migratory stream to the olfactory bulb to become interneurons. After cortical injury, elevated BMP-2 levels in the adult SVZ stemcell niche are translated into a rapid increase of Id 3 expression (Fig. 3). We showed that increased Id3 levels release the E47-mediated repression of astrocytespecific gene expression in adult NSPCs. Consequently, adult NSPCs preferentially differentiate into astrocytes. Id3-mediated astrogenesis from SVZ NSPCs is also triggered by fibrinogen (Fig. 3). Upon cortical photothrombosis, a mouse model for stroke, blood-derived fibrinogen is enriched in the SVZ niche and induces Id3 expression in SVZ NSPCs via activation of the BMP receptor signaling pathway and consequently induces NSPC differentiation into newborn astrocytes (Pous et al. 2020). Overall, these results reveal that the BMP signaling-induced Id3-E47 axis drives SVZ-derived reactive astrocyte contribution to the cortical scar formation after brain trauma. Interestingly, in mature neurons, Id 2 expression inhibits E47-induced transcription of the Nogo receptor, which is the key transducer of myelinmediated inhibition of axonal growth (Lasorella et al. 1996). Furthermore, Akt-mediated phosphorylation of Id 2 enhances Id 2 protein stability and steers Id 2 to the growth cone, where it interacts with radixin that is critical for growth cone formation (Ko et al. 2016). In line with these results, Id 2 can be overexpressed in neurons by interfering with its degradation with a D-box mutant Id2 adenoviral vector. This process reduced axon dieback and increased the number and length of regenerative fibers into the lesion gap after spinal cord injury (Yu et al. 2011), suggesting that modifying the Id-E47 balance in NSPCs and neurons might be an attractive route to promote CNS regeneration.

Multiple sclerosis MS is a chronic auto-inflammatory disease of the CNS characterized by blood-brain barrier (BBB) opening, leukocyte infiltration, and demyelination (Lassmann 2018). Insufficient oligodendrocyte precursor cells and the impeded differentiation of mature, myelinating oligodendrocytes are thought to be the major reasons of remyelination failure in MS patients (Franklin and Ffrench-Constant 2017). Similar to developmental stages, oligodendrogenesis in adulthood is regulated by several bHLH TFs, including Olig1 and Olig2 (Lu et al. 2002; Zhou and Anderson 2002), and Id 2 and Id4 are key inhibitors of oligodendrocyte differentiation (Kondo and Raff 2000; Marin-Husstege et al. 2006; Wang et al. 2001). 
Id 2 and Id4 directly interact with OLIG1 and OLIG2, inhibiting oligodendrocyte differentiation (Samanta and Kessler 2004). At present, the extracellular signals that control the operation of intracellular inhibitors or timers for oligodendrocyte maturation are not fully understood. In MS, upregulation of Id proteins within an inflammatory demyelinating environment perturbs the remyelination process. Besides increased BMP signaling (Cheng et al. 2007; Samanta and Kessler 2004), OPC contact with myelin increased Id 2 and Id 4 expression and stopped OPC differentiation (Plemel et al. 2013). The oligodendrocyte-specific G protein-coupled receptor GPR17 is a cell-intrinsic timer of myelination and in an $\mathrm{MOG}_{35-55}$-induced experimental autoimmune encephalomyelitis model of MS, the Olig1regulated GPR17 is upregulated in OPCs in the lesion and blocks oligodendrocyte maturation by increasing Id 2 and Id4 expression (Chen et al. 2009). Intriguingly, increased blood-derived fibrinogen deposition in human MS lesions increases Id protein expression in OPCs via the activation of BMP receptor signaling consequently blocking oligodendrocyte differentiation (Fig. 1) (Petersen et al. 2017). Both the Id3-E47-mediated astrocyte differentiation and the Id2/4-Olig1/2-mediated oligodendrocyte differentiation highlight the importance and functional divergence of each Id protein in NSPC lineage commitment. Thus, future therapeutic interventions targeting Id-specific abundance in NSPCs may serve as a potential target for increased myelinating oligodendrocytes in MS lesions and improved myelin repair.

Parkinson's disease The pathological hallmarks of PD are the progressive degeneration of nigrostriatal midbrain dopaminergic neurons and intraneuronal inclusions of $\alpha$-synuclein (O'Keeffe and Sullivan 2018; Spillantini et al. 1997). Id2-deficient mice display features of PD, such as a decrease of dopaminergic neurons in the olfactory bulb, accompanied by reduced olfactory discrimination (Havrda et al. 2008). While no deficiency of the stem-cell compartment was detected, migrating neuroblasts in $I d 2$-deficient mice prematurely undergo astroglial differentiation within a disorganized rostral migratory stream (Havrda et al. 2008). Furthermore, Id2-deficient mice showed age-dependent histological alterations in dopaminergic neurons of the substantia nigra pars compacta $(\mathrm{SNpC})$ associated with changes in locomotor activity. Dopamine transporter (DAT) expression was reduced at early ages in Id2-deficient mice, and DAT expression was shown to depend on Id 2 expression in an in vitro dopaminergic differentiation model. Evidence of neurodegeneration, including activated caspase- 3 and glial infiltration, were noted in the $\mathrm{SNpC}$ of older Id2-deficient mice. These findings document a key role for Id 2 in the maintenance of midbrain dopamine neurons (Havrda et al. 2013).

Besides Id2, other Ids might be involved in the regulation of the dopamine system. Id 1 and Id 3 are induced by dopamine suppression in primary cultured melanotrophs. Continuous stress results in decreased hypothalamic dopaminergic innervation to the intermediate lobe of the pituitary gland, which causes hyperactivation and subsequent degeneration of melanotrophs in the intermediate lobe. These results suggest that the decreased dopamine levels in the intermediate lobe during continuous stress induce Id 1 and Id 3 expression in melanotrophs. Because Id family members inhibit various bHLH transcription factors, the induced Id 1 and Id 3 might cooperatively modulate gene expression in melanotrophs under continuous stress conditions to induce hormone secretion (Konishi et al. 2010). These findings suggest that Ids are important in the progression of neurodegenerative disorders involving the dopamine system, such as PD, attention deficit hyperactivity disorder, schizophrenia, and drug abuse.

Glioblastoma GBM is the most aggressive primary brain tumor, and several studies implicated Id family members in disease development. Glioma stem cells, similar to type B adult NSPCs of the SVZ, are defined by their capacity to (1) self-renew in vitro, (2) transplant tumors in vivo, and (3) generate tumors that recapitulate the heterogeneity of the parental tumors (Stiles and Rowitch 2008). The degree to which glioma stem cells resemble neural stem cells and the degree to which the normal lineage hierarchy is maintained in brain tumors are unknown. In the normal neurogenic niche, Id genes maintain self-renewal and multipotency of adult neural stem cells. High Id 1 levels mark tumor cells with high self-renewal capacity, whereas low Id 1 levels identify tumor cells with proliferative potential but limited self-renewal capacity. Surprisingly, Id1low cells generate tumors more rapidly and with higher penetrance than Id1-high cells. Moreover, Id1-low cells are characterized by high levels of expression of progenitor-associated markers, including the bHLH transcription factor Olig2. Inhibition of Olig2 but not deletion of Id1 within Id1-low cells significantly prolongs the survival of tumor-bearing mice, underscoring the importance of nonself-renewing lineages in disease progression (Barrett et al. 2012).

Tumor cell invasion is a major contributor to cancer morbidity and is of particular importance in patients with GBM, the highest grade and most aggressive primary brain tumor. In stark contrast to Id1-3, Id4 correlates with survival of 
glioblastoma patients by decreasing MMP2 expression, a secreted proteinase key for brain tumor invasion, via a direct inhibitory interaction with the bHLH TF Twist1. Structural differences of Id4 might explain its unique function, compared to Id1-Id3 in astrocytic tumors, as Id4 has a unique polyalanine domain at the $\mathrm{N}$-terminus and a polyproline domain at the $\mathrm{C}$-terminus, which could convey specificity for the Id4/Twist1 interaction (Rahme and Israel 2015). Although GBM is an umbrella designation that includes a heterogeneous group of primary brain tumors, GBM exhibits common genetic characteristics. Among these, PDGF/ PDGFR-signaling activation appears in nearly $30 \%$ of patients and is especially enriched in a pro-neural subtype of GBM (Brennan et al. 2009). Id4 also increases PDGF and nitric oxide synthase 2 (NOS2) expression levels and enhanced the cell self-renewal function in GBM cell lines (Eun et al. 2017). These results place Id4 and its regulatory circuit system into the pole position for regulating the selfrenewal and tumor-initiating capacity of GBM stem cells and might provide a promising therapeutic target for GBM.

\section{Id tools for modifying neural stem-cell behavior}

The identification of Id protein function in NSPC fate specification implicates their potential as targets of NSPC manipulation for therapeutic purposes. Here, we describe the major tools to study Id functions in the nervous system: (1) genetic mouse lines with altered Id expression, (2) RNA interference technology, and (3) pharmacological intervention blocking Id-bHLH interaction or affecting Id abundance by blocking or promoting protein degradation (Table 1).

Genetic mouse lines During CNS development, the loss of Id genes leads to premature exit from active cycling and precocious differentiation of progenitor cells (Bedford et al. 2005; Lyden et al. 1999; Yun et al. 2004). Germline deletion of single Id member also reveals their functional divergence in cell-fate determination. In Id4-deficient mice, excessive mature oligodendrocytes in the subcortical white matter were found after birth, confirming the function of Id2/4 in oligodendrocyte development (MarinHusstege et al. 2006). Adult Id2-deficient mice revealed no obvious changes in stemcell proliferation in the CNS; however, loss of Id 2 results in a Hes1-mediated inhibition of dopaminergic neural differentiation with decreased generation of periglomerular cell layer interneurons in the olfactory bulb and defects in olfactory discrimination (Havrda et al. 2008). Furthermore, Id2-deficient mice revealed an age-dependent reduction of dopaminergic neuron numbers of the substantia nigra pars compacta associated with changes in locomotor activity (Havrda et al. 2013).

By characterizing Id3-deficient mice, our laboratory established Id3 as a target of blood-derived fibrinogeninduced BMP receptor signaling that determines the differentiation of endogenous NSPC into reactive astrocytes in the SVZ after cortical injury (Bohrer et al. 2015; Pous et al. 2020). With advances in the ability to make genetic modifications, conditional gene deletions allow cell-specific investigations of Id protein functions along temporal and spatial dimensions. Conditional inactivation of NSPC-specific Id1-3 revealed that Id proteins coordinate stemcell activities and triggered detachment of embryonic and postnatal NSPCs from the ventricular and vascular niches, respectively. Interrogation of the gene modules directly targeted by Id deletion in NSPCs revealed that Id proteins repress bHLH-mediated activation of Rap1GAP, the inhibitor of RAP1-GTPase, thus serving to maintain the GTPase activity of RAP1, a key mediator of cell adhesion. By preserving the anchorage of NSPCs to the extracellular environment, Id activity synchronizes NSPC functions to residency in the specialized niche (Niola et al. 2012). Quiescence is essential for the long-term maintenance of adult stem cells, but how stem cells maintain quiescence is poorly understood. Conditional Id4 deletion in hippocampal NSPCs resulted in abnormal accumulation of the bHLH TF Ascl1 and premature stem-cell activation. Id4 sequesters the Ascl1 heterodimerization partner E47, promoting Ascl1 protein degradation and stemcell quiescence (Blomfield et al. 2019).

These recent results highlight the importance of nontranscriptional mechanisms for the maintenance of NSPC quiescence and reveal a role for Id4 as a quiescenceinducing factor, in contrast to its role in promoting the proliferation of embryonic neural progenitors (Blomfield et al. 2019; Zhang et al. 2019). Overall, conditional inactivation of Id genes specifically in NSPCs showed that individual Id family members coordinate different stemcell properties.

RNA interference technology RNA interference (RNAi)based interventions, such as small interfering RNA (siRNA) and short hairpin RNA (shRNA), have already gained therapeutic applications (Sette et al. 2019). RNA interference technology for knocking down Id expression is broadly used in cancer research (e.g., siRNA targeting Id1 reduces glioblastoma cell invasion and self-renewal (Soroceanu et al. 2013), and implantation of Id2-shRNA knockdown 


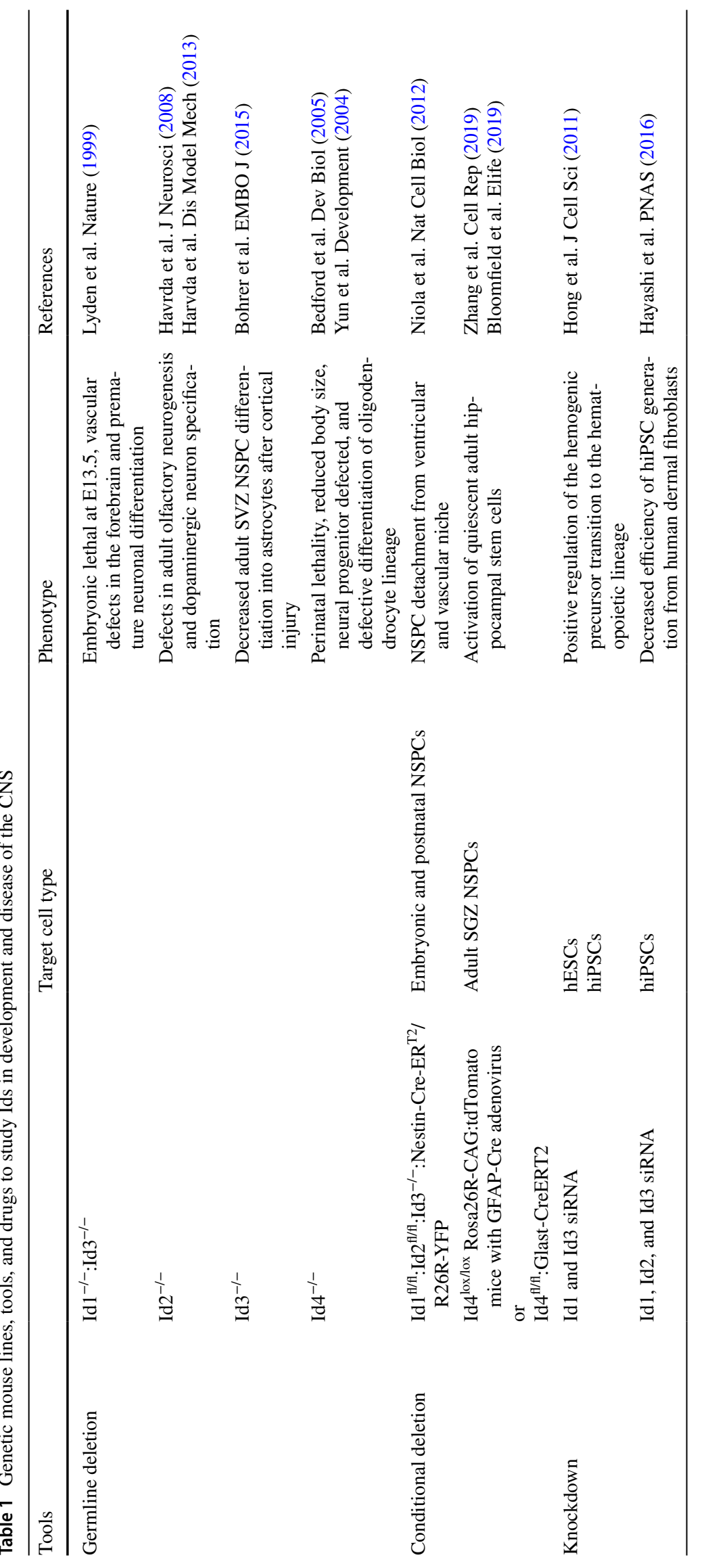




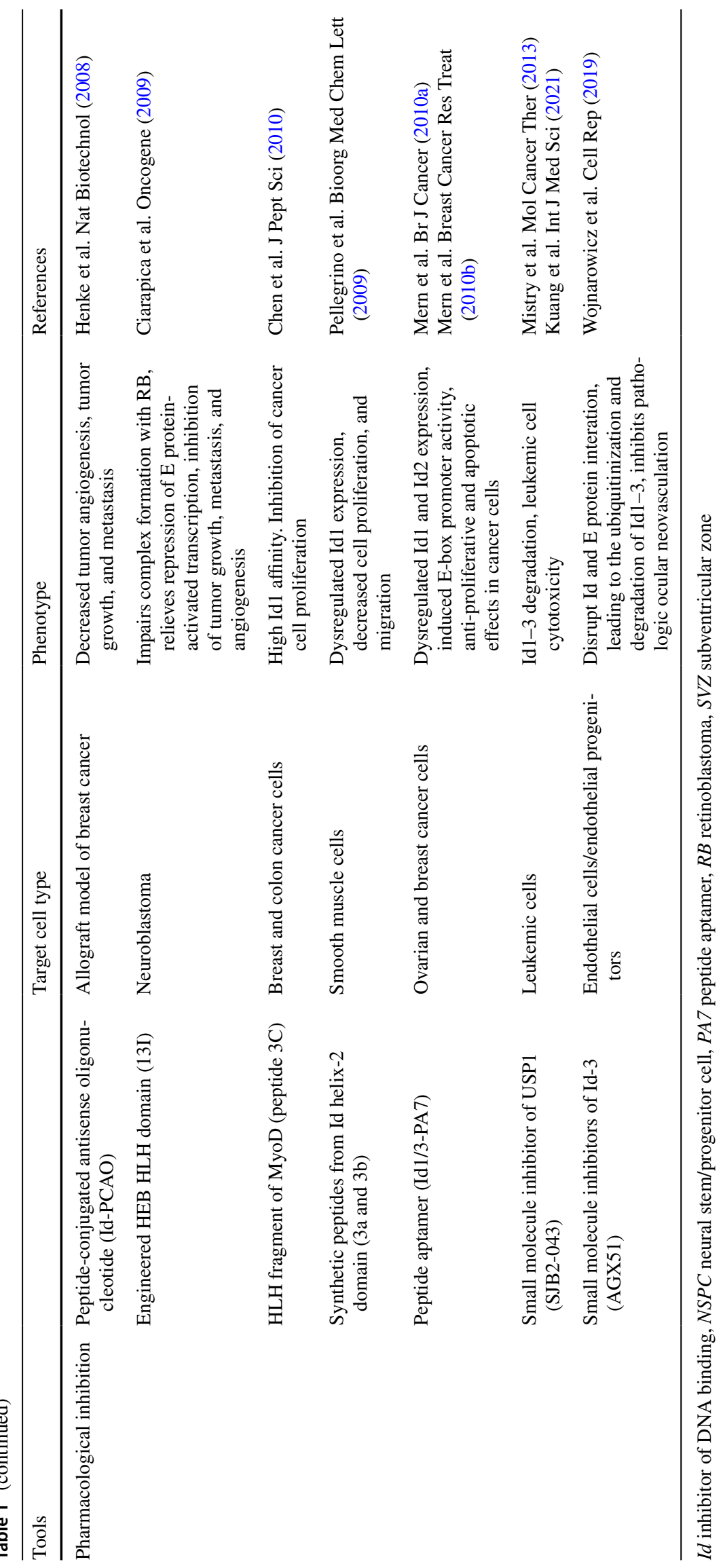


neuroblastoma cells into mice attenuates tumorigenicity, renders the cells immunogenic, and induces host immunity (Chakrabarti et al. 2015)). Id RNA interference technology was successfully applied in adult stemcell niches, where shRNA targeting Id3 regulates terminal differentiation of hippocampal (Micheli et al. 2017) and SVZ NSPCs (FarioliVecchioli et al. 2014).

Human pluripotent stemcell (hPSC) research has resulted in clinical applications for various CNS diseases and injuries, and RNA interference technology identified Ids as critical regulator in human embryonic stem cells (hESCs) and induced pluripotent stem cells (hiPSCs). Specific siRNA-mediated downregulation of Id1 and Id3 in either hESC or hiPSC-derived hemogenic precursors resulted in an increase in the generation of mature hematopoietic cells without changing the total cell number and viability of human embryoid bodies (Hong et al. 2011). Moreover, a recent study from Yamanaka's laboratory proved that siRNA-knockdown of Id1, Id2, or Id3 markedly decreased the efficiency of hiPSC generation from normal human-dermal fibroblasts, but overexpressing any Id gene by retroviral vectors showed an increase in the efficiency of iPSC generation (Hayashi et al. 2016). These results indicate that Id-targeted RNA interference might be a suitable technique to optimize the hPSC technology for therapeutic applications.

Pharmacological intervention Given their various functions in neurological diseases, Id members are attractive therapeutic targets for drug development. Targeted antisense approaches, peptides, and small molecules that can specifically reduce Id family protein abundance and modify Id protein functionality have been proved to be effective in cancer treatment. Indeed, Id protein inactivation by delivery of a peptide-conjugated antisense oligonucleotide, by modulation of Id degradation by the proteasome or by expression of engineered HLH dimerization partner, has been shown to inhibit tumor growth, metastasis and angiogenesis (Chen et al. 2010; Ciarapica et al. 2009; Henke et al. 2008; Kuang et al. 2021; Mistry et al. 2013). Another avenue to modulate the biological function of Id proteins is the development of synthetic molecules that interact with and conformationally perturb the Id HLH dimerization domain. The Id protein surface that recognizes and binds a bHLH protein is built from the parallel packing of helix-1 and helix-2 (Chavali et al. 2001). Consequently, an Id helix- 2 peptide mimic was shown to reduce Id1 expression and to modulate smooth muscle-cell proliferation and migration (Pellegrino et al. 2009). Similarly, a novel peptide aptamer, Id1/3-PA7, specifically interacting with Id 1 and Id3, was isolated from a randomized combinatorial expression library with yeast and mammalian twohybrid systems (Mern et al. 2010b). Id1/3-PA7 fused with a cell-protein transduction domain is an anti-tumor agent that triggers cell-cycle arrest and apoptosis in ovarian and breast cancer (Mern et al. 2010a). Moreover, recently, the Benezra laboratory identified the small-molecule pan-Id antagonist AGX51. AGX51 disrupts the Id and E-protein interactions, leading to destabilization of Id proteins and their ubiquitinmediated degradation. In pre-clinical experiments, AGX51 and derivatives phenocopied the genetic Id loss and inhibited pathologic ocular neovascularization and induced strong anti-tumor effects (Wojnarowicz et al. 2019). Thus, smallmolecule compounds, such as AGX51, the first-in-class compound that antagonizes the Id-E-protein interaction formerly considered undruggable, have potential for pharmacological intervention for Id proteins in CNS disease pathogenesis.

\section{Id proteins as potential targets for modifying neural stemcell behavior}

NSPCs hold great promise in physically replacing the damaged tissue after CNS injury and disease (Assinck et al. 2017; Fischer et al. 2020). However, injury-activated endogenous NSPCs predominantly produce scar-forming astrocytes, and the contribution of endogenous or transplanted NSPCs to cell replacement is insufficient for regeneration. We identified rapid and robust upregulation of Id proteins in pathological states with BBB opening as the central player for overriding intrinsic programming of glial and neuronal progenitor cells. Therefore, a targeted therapy against specific Id proteins to modulate the bHLH TF regulatory network might be an attractive and innovative perspective to render NSPCs resistant to the changed environment and to achieve the desired cell fate improving NSPC therapy for cell replacement and better functional restoration.

Indeed, a pioneer study aiming in identifying cellfate determinants after brain injury unraveled the bHLH TF Olig2 as a repressor of neurogenesis. Antagonizing Olig2 function in vivo resulted in a significant number of infected cells that generated immature neurons, not observed after injection of the control virus (Buffo et al. 2005). In addition, overexpression of the bHLH TFs Mash1 and Ngn2 enhanced NSPC survival and promoted robust neuronal differentiation after NSPC transplantation (Yi et al. 2008), and ectopic expression of Olig2 in adult ependymal cells, which are NSPCs in the spinal cord, led to efficient production of oligodendrocytes enabling spinal cord repair (Llorens-Bobadilla et al. 2020). These studies showed that NSPCs engineered via a modification of HLH TFs promote tissue repair after CNS injury or disease. Yet, the functional involvement of Id proteins in endogenous or transplanted NSPCs for cell replacement and CNS repair processes is only scarcely described. 


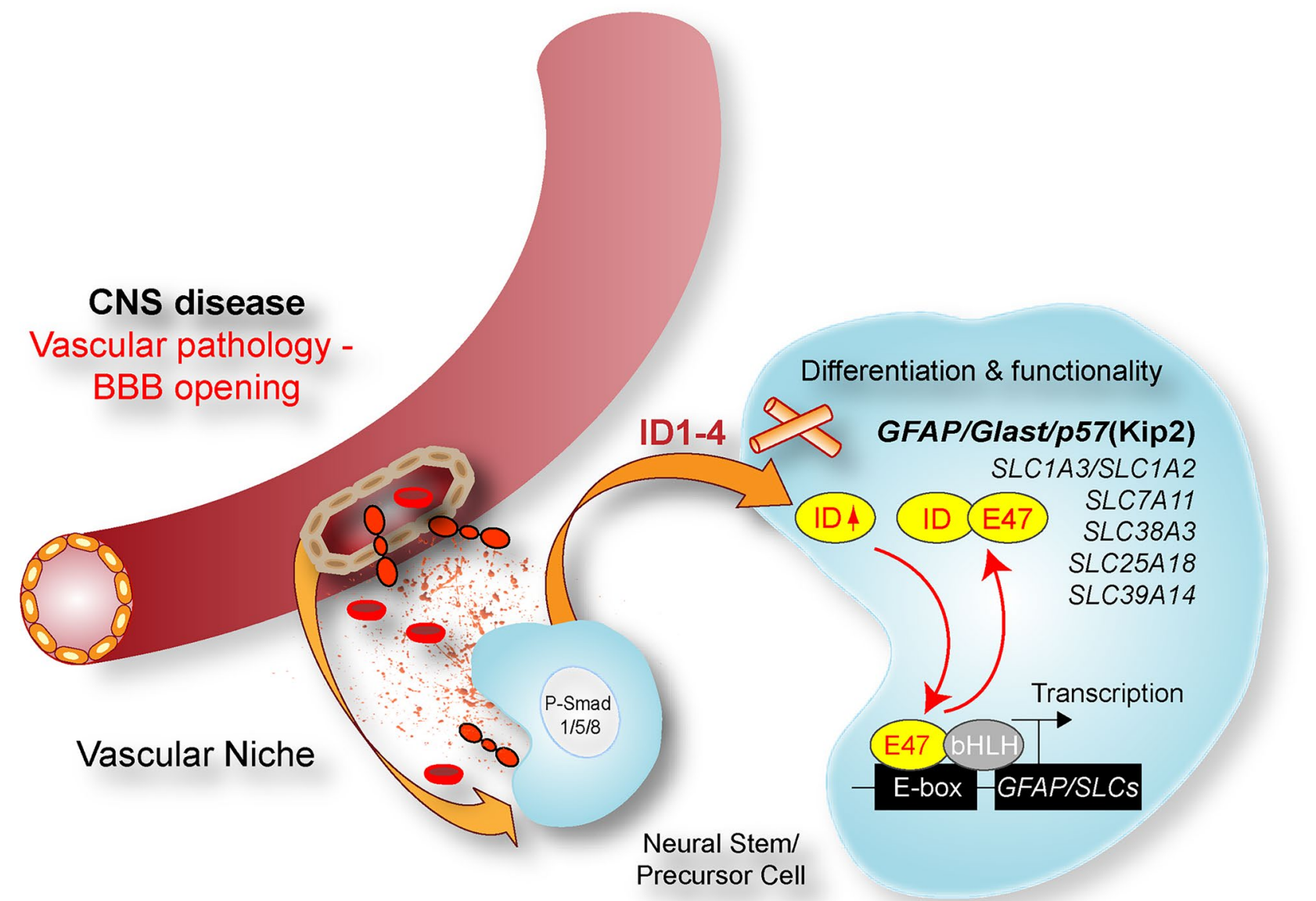

Fig. 4 Id function in NSPCs in CNS disease. Cortical injury results in increased SVZ vasculature permeability and fibrinogen deposition into the SVZ stem-cell-niche environment. The deposition of fibrinogen activates BMP signaling and induces phosphorylation of Smad1/5/8 in NSPCs and consequently upregulation of Ids. The Id3-controlled bHLH transcription factor E47 functioned as a tran-

Recently, our laboratory showed that excessive expression of Id3 in SVZ NSPCs after CNS injury scavenges the E47 bHLH transcriptional activity, which suppresses the expression of astrocyte-specific genes including GFAP and GLAST (also known as slcla3), thus promoting astrogenesis (Bohrer et al. 2015). Excessive expression of Id 2 triggered by fibrinogen deposition in demyelinated lesions of MS inhibits the translocation of class II bHLH TFs Olig1/2 into the nucleus, thus blocking the differentiation of OPCs into remyelinating oligodendrocyte (Petersen et al. 2017). Therefore, Id proteins may act as a central hub for translating extracellular signaling into cellular transcriptional properties by counteracting the transcriptional activity of bHLH TFs, and thus are keys in regulating adult NSPC differentiation in CNS injury and diseases.

Moreover, these results revealed that Id 2 and Id3 have differential interacting partner preferences towards specific bHLH members, which endow their functional divergence scriptional repressor of a subset of astrocyte-specific genes and genes belonging to the solute carrier (SLC) family, including Slc1a3 (GLAST) and Slc1a2 (GLUT1), suggesting a role of Id proteins in regulating cellular homeostasis and metabolism upon environmental alteration

in regulating NSPC fate. Indeed, although highly conserved in the HLH domain, Id2 is structurally different compared to Id3 in the $\mathrm{N}$ - and C-terminal parts (e.g., Id2, but not Id3, contains a D-box and nuclear export signal in its C-terminus) (Kurooka and Yokota 2005; Lasorella et al. 2006). Structural and functional differences between Id family members imply the option of modifying specific Id members in a cell- and/ or disease-dependent manner.

NSPCs have immunomodulatory functions, in addition to their function to replace lost tissue. Compelling evidence from experimental animal disease models and earlyphase clinical trials identified transplanted NSPCs to act as local "source" for producing and secreting a wide array of neurotrophic and immunomodulatory factors (Martino and Pluchino 2006)(Ziv et al. 2006). Importantly, NSPCs regulate the functional aspects of myeloid cells. NSPCs of the SVZ revealed a secretory protein profile distinct from 


\section{Chronic Inflammation}

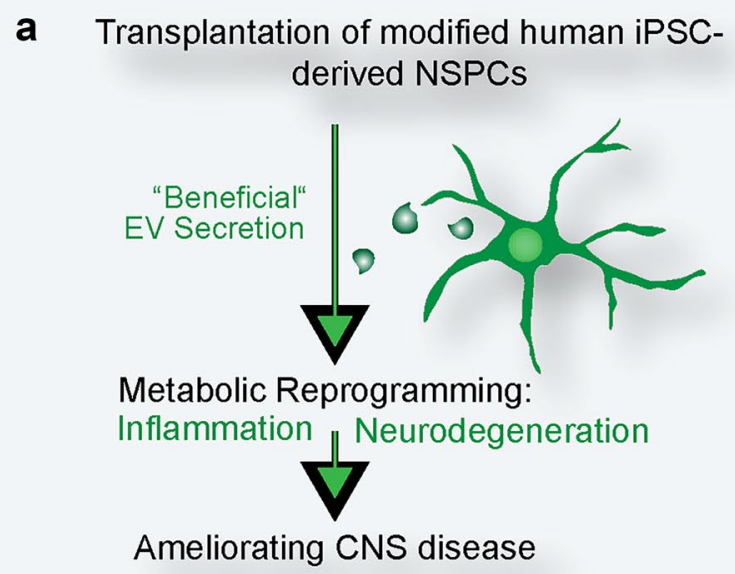

b Phenotypical characterization

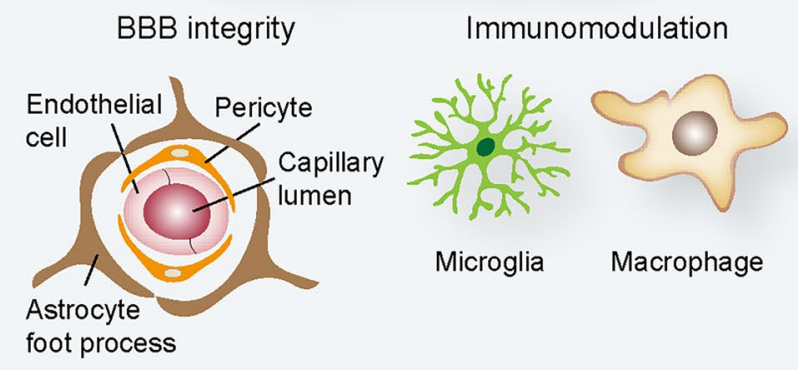

C

EV isolation \& analysis

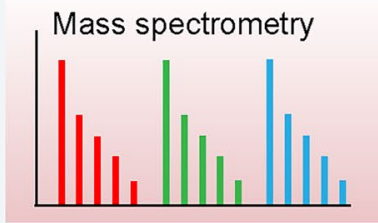

RNA \& miRNA sequencing
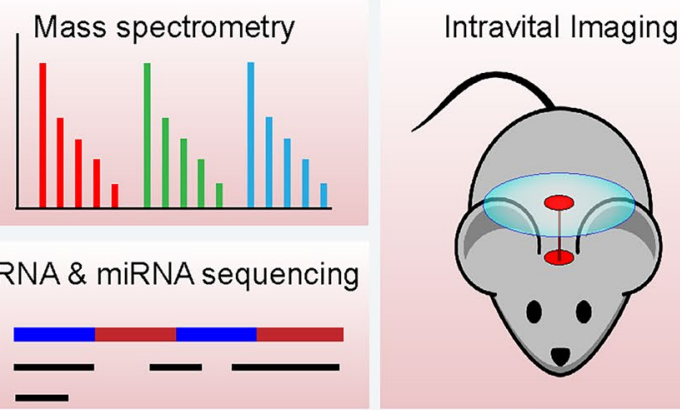

Fig. 5 Potential role for Id proteins in modulating NSPC behavior ameliorating CNS diseases. (a) Cell transplantation of $I d$-depleted human iPSC-derived NSPCs may result in EV secretion with beneficial effects. (b) Phenotypical characterization of $I d$-depleted human iPSC-derived NSPCs on BBB integrity and on myeloid cell activation. (c) To discover potential immunomodulatory roles of $I d$ depleted human iPSC-derived NSPCs, EV bio-contents, such as mRNA, miRNA, and protein, can be analyzed by mass spectrometry and RNA sequencing, and EV distribution can be visualized via intravital imaging other brain cells modulating microglial activation, proliferation, and phagocytosis. NSPC-derived VEGF was necessary and sufficient to exert at least some of these effects in mice (Mosher et al. 2012). NSPCs secrete extracellular vesicles, which encase proteins and microRNAs that act as morphogens to preferentially target microglia regulating their morphology and immune responses (Morton et al. 2018). Additionally, under chronic inflammatory condition, NSPCs ameliorate neuroinflammation by detecting the extracellular succinate released by mononuclear phagocytes. The uptake of extracellular succinate, which is released by the inflammatory mononuclear phagocyte, upregulates the succinate co-transporter of the SLC family in the NSPCs and triggers the secretion of prostaglandin E2 by the NSPCs with consequential anti-inflammatory effects (Peruzzotti-Jametti et al. 2018). Interestingly, our study identified that the Id-E47 axis regulates, besides GLAST, several other members of the SLC family, such as Slcla2, Slc25a18, Slc38a3, Slc39a14, and Slc7a11 (Bohrer et al. 2015) (Fig. 4). SLC family members are broadly involved in glutamate transport, intracellular ionic balance, and vesicle transport, suggesting a potential function of Id signaling in directing cellular homeostasis and metabolism in NSPCs upon environmental alteration (Lin et al. 2021). In addition, Id abundance regulates cytokine release, such as VEGF, GRO $\alpha$ (also known as CXCL1), and IL-8 (Fontemaggi et al. 2009; Jin et al. 2011; Lasorella et al. 2005; Lin et al. 2021). Therefore, modifying Id expression in endogenous or transplanted NSPCs may lead to an altered cellular functionality and cytokine/EV release, potentially reducing neuroinflammation and neurodegeneration (Fig. 5). To this end, using CRISPR/Cas9 technology and small-molecule inhibitors to delete Id proteins may help address this issue without affecting important functions of the BMP signaling pathway in stem-cell proliferation and differentiation.

\section{Concluding remarks}

Ids are potent regulators of glial and neural stemcell behavior in different CNS injuries and diseases, such as stroke, trauma, MS, PD, and GBM. Ids are unstable, rapidly regulated proteins that hinder the bHLH transcription factor DNA-binding activity by modifying its regulatory network. Although Id proteins were formerly considered undruggable, recent developments in small-molecule compounds regulating Id-E-protein interactions allow control of Id levels in glial and neural stem cells. Thus, pharmacological intervention involving Id proteins has potential to modify stemcell behavior and ameliorate CNS disease. Several key issues remain to be resolved. Optimal Id targeting requires 
a greater understanding of the cell types and injury states in which Id family members and their interaction partners are co-expressed and their mode of interactions. Over the next few years, we expect that research will elucidate the function of the individual Id proteins in CNS disease and their underlying molecular mechanisms, the identification of unique interaction sites for Id targeting, and how individual Id depletion alters the stemcell functionality.

Acknowledgements We thank Andreas Schober for the graphics. A draft of this manuscript was edited by Gary Howard.

Funding Open Access funding enabled and organized by Projekt DEAL. This work was supported by the German Research Foundation grants SCHA $1442 / 8-1$ and $1442 / 9-1$ to C.S.

\section{Declarations}

Ethical approval This article does not contain any studies with human participants or animals performed by any of the authors.

Conflict of interest The authors declare no competing interests.

Open Access This article is licensed under a Creative Commons Attribution 4.0 International License, which permits use, sharing, adaptation, distribution and reproduction in any medium or format, as long as you give appropriate credit to the original author(s) and the source, provide a link to the Creative Commons licence, and indicate if changes were made. The images or other third party material in this article are included in the article's Creative Commons licence, unless indicated otherwise in a credit line to the material. If material is not included in the article's Creative Commons licence and your intended use is not permitted by statutory regulation or exceeds the permitted use, you will need to obtain permission directly from the copyright holder. To view a copy of this licence, visit http://creativecommons.org/licenses/by/4.0/.

\section{References}

Amado T, Amorim A, Enguita FJ, Romero PV, Inacio D, de Miranda MP, Winter SJ, Simas JP, Krueger A, Schmolka N, Silva-Santos B, Gomes AQ (2020) MicroRNA-181a regulates IFN-gamma expression in effector CD8(+) T cell differentiation. J Mol Med (berl) 98:309-320

Annibali D, Gioia U, Savino M, Laneve P, Caffarelli E, Nasi S (2012) A new module in neural differentiation control: two microRNAs upregulated by retinoic acid, miR-9 and -103, target the differentiation inhibitor ID2. PLoS One 7:e40269

Assinck P, Duncan GJ, Hilton BJ, Plemel JR, Tetzlaff W (2017) Cell transplantation therapy for spinal cord injury. Nat Neurosci 20:637-647

Barrett LE, Granot Z, Coker C, Iavarone A, Hambardzumyan D, Holland EC, Nam HS, Benezra R (2012) Self-renewal does not predict tumor growth potential in mouse models of high-grade glioma. Cancer Cell 21:11-24

Bedford L, Walker R, Kondo T, van Cruchten I, King ER, Sablitzky F (2005) Id4 is required for the correct timing of neural differentiation. Dev Biol 280:386-395

Beisswenger M, Cabrele C (2014) Self-recognition behavior of a helixloop-helix domain by a fragment scan. Biochim Biophys Acta 1844:1675-1683
Beisswenger M, Yoshiya T, Kiso Y, Cabrele C (2010) Synthesis and conformation of an analog of the helix-loop-helix domain of the Id1 protein containing the O-acyl iso-prolyl-seryl switch motif. J Pept Sci 16:303-308

Berse M, Bounpheng M, Huang X, Christy B, Pollmann C, Dubiel W (2004) Ubiquitin-dependent degradation of Id1 and Id3 is mediated by the COP9 signalosome. J Mol Biol 343:361-370

Bertrand N, Castro DS, Guillemot F (2002) Proneural genes and the specification of neural cell types. Nat Rev Neurosci 3:517-530

Blomfield IM, Rocamonde B, Masdeu MDM, Mulugeta E, Vaga S, van den Berg DL, Huillard E, Guillemot F, Urban N (2019) Id4 promotes the elimination of the pro-activation factor Ascl1 to maintain quiescence of adult hippocampal stem cells. eLife 8

Bohrer C, Pfurr S, Mammadzada K, Schildge S, Plappert L, Hils M, Pous L, Rauch KS, Dumit VI, Pfeifer D, Dengjel J, Kirsch M, Schachtrup K, Schachtrup C (2015) The balance of Id3 and E47 determines neural stem/precursor cell differentiation into astrocytes. EMBO J 34:2804-2819

Bonaguidi MA, Peng CY, McGuire T, Falciglia G, Gobeske KT, Czeisler C, Kessler JA (2008) Noggin expands neural stem cells in the adult hippocampus. J Neurosci 28:9194-9204

Borlak J, Meier T, Halter R, Spanel R, Spanel-Borowski K (2005) Epidermal growth factor-induced hepatocellular carcinoma: gene expression profiles in precursor lesions, early stage and solitary tumours. Oncogene 24:1809-1819

Bounpheng MA, Dimas JJ, Dodds SG, Christy BA (1999) Degradation of Id proteins by the ubiquitin-proteasome pathway. FASEB J 13:2257-2264

Brennan C, Momota H, Hambardzumyan D, Ozawa T, Tandon A, Pedraza A, Holland E (2009) Glioblastoma subclasses can be defined by activity among signal transduction pathways and associated genomic alterations. PLoS One 4:e7752

Buffo A, Vosko MR, Erturk D, Hamann GF, Jucker M, Rowitch D, Gotz M (2005) Expression pattern of the transcription factor Olig2 in response to brain injuries: implications for neuronal repair. Proc Natl Acad Sci U S A 102:18183-18188

Chaker Z, Codega P, Doetsch F (2016) A mosaic world: puzzles revealed by adult neural stem cell heterogeneity. Wiley Interdiscip Rev Dev Biol 5:640-658

Chakrabarti L, Morgan C, Sandler AD (2015) Combination of Id2 knockdown whole tumor cells and checkpoint blockade: a potent vaccine strategy in a mouse neuroblastoma model. PLoS One 10:e0129237

Chavali GB, Vijayalakshmi C, Salunke DM (2001) Analysis of sequence signature defining functional specificity and structural stability in helix-loop-helix proteins. Proteins 42:471-480

Chen CH, Kuo SC, Huang LJ, Hsu MH, Lung FD (2010) Affinity of synthetic peptide fragments of MyoD for Id1 protein and their biological effects in several cancer cells. J Pept Sci 16:231-241

Chen Y, Wu H, Wang S, Koito H, Li J, Ye F, Hoang J, Escobar SS, Gow A, Arnett HA, Trapp BD, Karandikar NJ, Hsieh J, Lu QR (2009) The oligodendrocyte-specific G protein-coupled receptor GPR17 is a cell-intrinsic timer of myelination. Nat Neurosci 12:1398-1406

Cheng X, Wang Y, He Q, Qiu M, Whittemore SR, Cao Q (2007) Bone morphogenetic protein signaling and olig1/2 interact to regulate the differentiation and maturation of adult oligodendrocyte precursor cells. Stem Cells 25:3204-3214

Ciarapica R, Annibali D, Raimondi L, Savino M, Nasi S, Rota R (2009) Targeting Id protein interactions by an engineered HLH domain induces human neuroblastoma cell differentiation. Oncogene 28:1881-1891

Cochrane SW, Zhao Y, Welner RS, Sun XH (2009) Balance between Id and $\mathrm{E}$ proteins regulates myeloid-versus-lymphoid lineage decisions. Blood 113:1016-1026 
Colombo N, Cabrele C (2006) Synthesis and conformational analysis of Id2 protein fragments: impact of chain length and point mutations on the structural HLH motif. J Pept Sci 12:550-558

Deed RW, Hara E, Atherton GT, Peters G, Norton JD (1997) Regulation of Id3 cell cycle function by Cdk-2-dependent phosphorylation. Mol Cell Biol 17:6815-6821

Dennis DJ, Han S, Schuurmans C (2019) bHLH transcription factors in neural development, disease, and reprogramming. Brain Res 1705:48-65

Eletsky A, Ruyechan WT, Xiao R, Acton TB, Montelione GT, Szyperski $\mathrm{T}$ (2011) Solution NMR structure of MED25(391-543) comprising the activator-interacting domain (ACID) of human mediator subunit 25. J Struct Funct Genomics 12:159-166

Eun K, Jeon HM, Kim SO, Choi SH, Lee SY, Jin X, Kim SC, Kim H (2017) A cell-autonomous positive-signaling circuit associated with the PDGF-NO-ID4-regulatory axis in glioblastoma cells. Biochem Biophys Res Commun 486:564-570

Farioli-Vecchioli S, Ceccarelli M, Saraulli D, Micheli L, Cannas S, D'Alessandro F, Scardigli R, Leonardi L, Cina I, Costanzi M, Mattera A, Cestari V, Tirone F (2014) Tis21 is required for adult neurogenesis in the subventricular zone and for olfactory behavior regulating cyclins, BMP4, Hes1/5 and Ids. Front Cell Neurosci 8:98

Fischer I, Dulin JN, Lane MA (2020) Transplanting neural progenitor cells to restore connectivity after spinal cord injury. Nat Rev Neurosci 21:366-383

Fontemaggi G, Dell'Orso S, Trisciuoglio D, Shay T, Melucci E, Fazi F, Terrenato I, Mottolese M, Muti P, Domany E, Del Bufalo D, Strano S, Blandino G (2009) The execution of the transcriptional axis mutant p53, E2F1 and ID4 promotes tumor neo-angiogenesis. Nat Struct Mol Biol 16:1086-1093

Franklin RJM, Ffrench-Constant C (2017) Regenerating CNS myelin from mechanisms to experimental medicines. Nat Rev Neurosci 18:753-769

Hara E, Hall M, Peters G (1997) Cdk2-dependent phosphorylation of Id 2 modulates activity of E2A-related transcription factors. EMBO J 16:332-342

Havrda MC, Harris BT, Mantani A, Ward NM, Paolella BR, Cuzon VC, Yeh HH, Israel MA (2008) Id2 is required for specification of dopaminergic neurons during adult olfactory neurogenesis. J Neurosci 28:14074-14086

Havrda MC, Paolella BR, Ward NM, Holroyd KB (2013) Behavioral abnormalities and Parkinson's-like histological changes resulting from Id2 inactivation in mice. Dis Model Mech 6:819-827

Hayashi Y, Hsiao EC, Sami S, Lancero M, Schlieve CR, Nguyen T, Yano K, Nagahashi A, Ikeya M, Matsumoto Y, Nishimura K, Fukuda A, Hisatake K, Tomoda K, Asaka I, Toguchida J, Conklin BR, Yamanaka S (2016) BMP-SMAD-ID promotes reprogramming to pluripotency by inhibiting p16/INK4A-dependent senescence. Proc Natl Acad Sci U S A 113:13057-13062

Henke E, Perk J, Vider J, de Candia P, Chin Y, Solit DB, Ponomarev V, Cartegni L, Manova K, Rosen N, Benezra R (2008) Peptideconjugated antisense oligonucleotides for targeted inhibition of a transcriptional regulator in vivo. Nat Biotechnol 26:91-100

Hollnagel A, Oehlmann V, Heymer J, Ruther U, Nordheim A (1999) Id genes are direct targets of bone morphogenetic protein induction in embryonic stem cells. J Biol Chem 274:19838-19845

Hong SH, Lee JH, Lee JB, Ji J, Bhatia M (2011) ID1 and ID3 represent conserved negative regulators of human embryonic and induced pluripotent stem cell hematopoiesis. J Cell Sci 124:1445-1452

Iavarone A, Garg P, Lasorella A, Hsu J, Israel MA (1994) The helixloop-helix protein Id-2 enhances cell proliferation and binds to the retinoblastoma protein. Genes Dev 8:1270-1284

Ihrie RA, Alvarez-Buylla A (2011) Lake-front property: a unique germinal niche by the lateral ventricles of the adult brain. Neuron 70:674-686

Jin X, Yin J, Kim SH, Sohn YW, Beck S, Lim YC, Nam DH, Choi YJ, Kim H (2011) EGFR-AKT-Smad signaling promotes formation of glioma stem-like cells and tumor angiogenesis by ID3-driven cytokine induction. Can Res 71:7125-7134

Kang Y, Chen CR, Massague J (2003) A self-enabling TGFbeta response coupled to stress signaling: Smad engages stress response factor ATF3 for Id1 repression in epithelial cells. Mol Cell 11:915-926

Karaya K, Mori S, Kimoto H, Shima Y, Tsuji Y, Kurooka H, Akira S, Yokota Y (2005) Regulation of Id2 expression by CCAAT/ enhancer binding protein beta. Nucleic Acids Res 33:1924-1934

Katagiri T, Imada M, Yanai T, Suda T, Takahashi N, Kamijo R (2002) Identification of a BMP-responsive element in Id1, the gene for inhibition of myogenesis. Genes Cells 7:949-960

Kiewitz SD, Cabrele C (2005) Synthesis and conformational properties of protein fragments based on the Id family of DNA-binding and cell-differentiation inhibitors. Biopolymers 80:762-774

Kiewitz SD, Kakizawa T, Kiso Y, Cabrele C (2008) Switching from the unfolded to the folded state of the helix-loop-helix domain of the Id proteins based on the O-acyl isopeptide method. J Pept Sci 14:1209-1215

Ko HR, Kwon IS, Hwang I, Jin EJ, Shin JH, Brennan-Minnella AM, Swanson R, Cho SW, Lee KH, Ahn JY (2016) Akt1-inhibitor of DNA binding2 is essential for growth cone formation and axon growth and promotes central nervous system axon regeneration. eLife 5

Kondo T, Raff M (2000) The Id4 HLH protein and the timing of oligodendrocyte differentiation. EMBO J 19:1998-2007

Konishi H, Ogawa T, Nakagomi S, Inoue K, Tohyama M, Kiyama H (2010) Id1, Id 2 and Id 3 are induced in rat melanotrophs of the pituitary gland by dopamine suppression under continuous stress. Neuroscience 169:1527-1534

Kuang X, Xiong J, Lu T, Wang W, Zhang Z, Wang J (2021) Inhibition of USP1 induces apoptosis via ID1/AKT pathway in B-cell acute lymphoblastic leukemia cells. Int J Med Sci 18:245-255

Kurooka H, Yokota Y (2005) Nucleo-cytoplasmic shuttling of Id2, a negative regulator of basic helix-loop-helix transcription factors. J Biol Chem 280:4313-4320

Langlands K, Yin X, Anand G, Prochownik EV (1997) Differential interactions of Id proteins with basic-helix-loop-helix transcription factors. J Biol Chem 272:19785-19793

Lasorella A, Benezra R, Iavarone A (2014) The ID proteins: master regulators of cancer stem cells and tumour aggressiveness. Nat Rev Cancer 14:77-91

Lasorella A, Iavarone A, Israel MA (1996) Id2 specifically alters regulation of the cell cycle by tumor suppressor proteins. Mol Cell Biol 16:2570-2578

Lasorella A, Noseda M, Beyna M, Yokota Y, Iavarone A (2000) Id2 is a retinoblastoma protein target and mediates signalling by Myc oncoproteins. Nature 407:592-598

Lasorella A, Rothschild G, Yokota Y, Russell RG, Iavarone A (2005) Id2 mediates tumor initiation, proliferation, and angiogenesis in Rb mutant mice. Mol Cell Biol 25:3563-3574

Lasorella A, Stegmuller J, Guardavaccaro D, Liu G, Carro MS, Rothschild G, de la Torre-Ubieta L, Pagano M, Bonni A, Iavarone A (2006) Degradation of Id 2 by the anaphase-promoting complex couples cell cycle exit and axonal growth. Nature 442:471-474

Lassmann H (2018) Multiple sclerosis pathology. Cold Spring Harb Perspect Med 8:

Leeanansaksiri W, Wang H, Gooya JM, Renn K, Abshari M, Tsai S, Keller JR (2005) IL-3 induces inhibitor of DNA-binding protein-1 in hemopoietic progenitor cells and promotes myeloid cell development. J Immunol 174:7014-7021

Liang YY, Brunicardi FC, Lin X (2009) Smad3 mediates immediate early induction of Id1 by TGF-beta. Cell Res 19:140-148

Lin JD, Chu YH, Nath S, Schachtrup C (2021) Fibrinogen triggered signaling pathways modify stem cell behavior in central nervous system disease. Neural Regen Res 16:1196-1197 
Linding R, Jensen LJ, Diella F, Bork P, Gibson TJ, Russell RB (2003) Protein disorder prediction: implications for structural proteomics. Structure 11:1453-1459

Lingbeck JM, Trausch-Azar JS, Ciechanover A, Schwartz AL (2005) E12 and E47 modulate cellular localization and proteasome-mediated degradation of MyoD and Id1. Oncogene 24:6376-6384

Llorens-Bobadilla E, Chell JM, Le Merre P, Wu Y, Zamboni M, Bergenstrahle J, Stenudd M, Sopova E, Lundeberg J, Shupliakov O, Carlen M, Frisen J (2020) A latent lineage potential in resident neural stem cells enables spinal cord repair. Science 370:

Lu P, Wang Y, Graham L, McHale K, Gao M, Wu D, Brock J, Blesch A, Rosenzweig ES, Havton LA, Zheng B, Conner JM, Marsala M, Tuszynski MH (2012) Long-distance growth and connectivity of neural stem cells after severe spinal cord injury. Cell 150:1264-1273

Lu QR, Sun T, Zhu Z, Ma N, Garcia M, Stiles CD, Rowitch DH (2002) Common developmental requirement for Olig function indicates a motor neuron/oligodendrocyte connection. Cell 109:75-86

Lyden D, Young AZ, Zagzag D, Yan W, Gerald W, O'Reilly R, Bader BL, Hynes RO, Zhuang Y, Manova K, Benezra R (1999) Id1 and Id 3 are required for neurogenesis, angiogenesis and vascularization of tumour xenografts. Nature 401:670-677

Maeda K, Malykhin A, Teague-Weber BN, Sun XH, Farris AD, Coggeshall KM (2009) Interleukin-6 aborts lymphopoiesis and elevates production of myeloid cells in systemic lupus erythematosus-prone B6.Sle1. Yaa animals. Blood 113:4534-4540

Makita J, Kurooka H, Mori K, Akagi Y, Yokota Y (2006) Identification of the nuclear export signal in the helix-loop-helix inhibitor Id1. FEBS Lett 580:1812-1816

Marin-Husstege M, He Y, Li J, Kondo T, Sablitzky F, Casaccia-Bonnefil P (2006) Multiple roles of Id4 in developmental myelination: predicted outcomes and unexpected findings. Glia 54:285-296

Martino G, Pluchino S (2006) The therapeutic potential of neural stem cells. Nat Rev Neurosci 7:395-406

Mern DS, Hasskarl J, Burwinkel B (2010a) Inhibition of Id proteins by a peptide aptamer induces cell-cycle arrest and apoptosis in ovarian cancer cells. Br J Cancer 103:1237-1244

Mern DS, Hoppe-Seyler K, Hoppe-Seyler F, Hasskarl J, Burwinkel B (2010b) Targeting Id1 and Id3 by a specific peptide aptamer induces E-box promoter activity, cell cycle arrest, and apoptosis in breast cancer cells. Breast Cancer Res Treat 124:623-633

Micheli L, Ceccarelli M, Gioia R, D’Andrea G, Farioli-Vecchioli S, Costanzi M, Saraulli D, Cestari V, Tirone F (2017) Terminal differentiation of adult hippocampal progenitor cells is a step functionally dissociable from proliferation and is controlled by Tis 21, Id3 and NeuroD2. Front Cell Neurosci 11:186

Mira H, Andreu Z, Suh H, Lie DC, Jessberger S, Consiglio A, San Emeterio J, Hortiguela R, Marques-Torrejon MA, Nakashima K, Colak D, Gotz M, Farinas I, Gage FH (2010) Signaling through BMPR-IA regulates quiescence and long-term activity of neural stem cells in the adult hippocampus. Cell Stem Cell 7:78-89

Mistry H, Hsieh G, Buhrlage SJ, Huang M, Park E, Cuny GD, Galinsky I, Stone RM, Gray NS, D’Andrea AD, Parmar K (2013) Smallmolecule inhibitors of USP1 target ID1 degradation in leukemic cells. Mol Cancer Ther 12:2651-2662

Miyazono K, Miyazawa K (2002) Id: a target of BMP signaling. Sci STKE 2002:pe40

Morton MC, Neckles VN, Seluzicki CM, Holmberg JC, Feliciano DM (2018) Neonatal Subventricular Zone Neural Stem Cells Release Extracellular Vesicles that Act as a Microglial Morphogen. Cell Rep 23:78-89

Mosher KI, Andres RH, Fukuhara T, Bieri G, Hasegawa-Moriyama M, He Y, Guzman R, Wyss-Coray T (2012) Neural progenitor cells regulate microglia functions and activity. Nat Neurosci 15:1485-1487
Murre C (2019) Helix-loop-helix proteins and the advent of cellular diversity: 30 years of discovery. Genes Dev 33:6-25

Nakahiro T, Kurooka H, Mori K, Sano K, Yokota Y (2010) Identification of BMP-responsive elements in the mouse Id2 gene. Biochem Biophys Res Commun 399:416-421

Nakashima K, Takizawa T, Ochiai W, Yanagisawa M, Hisatsune T, Nakafuku M, Miyazono K, Kishimoto T, Kageyama R, Taga T (2001) BMP2-mediated alteration in the developmental pathway of fetal mouse brain cells from neurogenesis to astrocytogenesis. Proc Natl Acad Sci U S A 98:5868-5873

Nam HS, Benezra R (2009) High levels of Id1 expression define B1 type adult neural stem cells. Cell Stem Cell 5:515-526

Niola F, Zhao X, Singh D, Castano A, Sullivan R, Lauria M, Nam HS, Zhuang Y, Benezra R, Di Bernardo D, Iavarone A, Lasorella A (2012) Id proteins synchronize stemness and anchorage to the niche of neural stem cells. Nat Cell Biol 14:477-487

Norton JD, Deed RW, Craggs G, Sablitzky F (1998) Id helix-loophelix proteins in cell growth and differentiation. Trends Cell Biol 8:58-65

O'Keeffe GW, Sullivan AM (2018) Evidence for dopaminergic axonal degeneration as an early pathological process in Parkinson's disease. Parkinsonism Relat Disord 56:9-15

Obradovic Z, Peng K, Vucetic S, Radivojac P, Dunker AK (2005) Exploiting heterogeneous sequence properties improves prediction of protein disorder. Proteins 61(Suppl 7):176-182

Pan WL, Chopp M, Fan B, Zhang R, Wang X, Hu J, Zhang XM, Zhang ZG, Liu XS (2019) Ablation of the microRNA-17-92 cluster in neural stem cells diminishes adult hippocampal neurogenesis and cognitive function. FASEB J 33:5257-5267

Passiatore G, Gentilella A, Rom S, Pacifici M, Bergonzini V, Peruzzi F (2011) Induction of Id-1 by FGF-2 involves activity of EGR-1 and sensitizes neuroblastoma cells to cell death. J Cell Physiol 226:1763-1770

Pellegrino S, Ferri N, Colombo N, Cremona E, Corsini A, Fanelli R, Gelmi ML, Cabrele C (2009) Synthetic peptides containing a conserved sequence motif of the Id protein family modulate vascular smooth muscle cell phenotype. Bioorg Med Chem Lett 19:6298-6302

Peruzzotti-Jametti L, Bernstock JD, Vicario N, Costa ASH, Kwok CK, Leonardi T, Booty LM, Bicci I, Balzarotti B, Volpe G, Mallucci G, Manferrari G, Donega M, Iraci N, Braga A, Hallenbeck JM, Murphy MP, Edenhofer F, Frezza C, Pluchino S (2018) Macrophagederived extracellular succinate licenses neural stem cells to suppress chronic neuroinflammation. Cell Stem Cell 22:355-368 e313

Petersen MA, Ryu JK, Chang KJ, Etxeberria A, Bardehle S, Mendiola AS, Kamau-Devers W, Fancy SPJ, Thor A, Bushong EA, BaezaRaja B, Syme CA, Wu MD, Rios Coronado PE, Meyer-Franke A, Yahn S, Pous L, Lee JK, Schachtrup C, Lassmann H, Huang EJ, Han MH, Absinta M, Reich DS, Ellisman MH, Rowitch DH, Chan JR, Akassoglou K (2017) Fibrinogen activates BMP signaling in oligodendrocyte progenitor cells and inhibits remyelination after vascular damage. Neuron 96:1003-1012 e1007

Plemel JR, Manesh SB, Sparling JS, Tetzlaff W (2013) Myelin inhibits oligodendroglial maturation and regulates oligodendrocytic transcription factor expression. Glia 61:1471-1487

Pluchino S, Smith JA, Peruzzotti-Jametti L (2020) Promises and limitations of neural stem cell therapies for progressive multiple sclerosis. Trends Mol Med 26:898-912

Pous L, Deshpande SS, Nath S, Mezey S, Malik SC, Schildge S, Bohrer C, Topp K, Pfeifer D, Fernandez-Klett F, Doostkam S, Galanakis DK, Taylor V, Akassoglou K, Schachtrup C (2020) Fibrinogen induces neural stem cell differentiation into astrocytes in the subventricular zone via BMP signaling. Nat Commun 11:630

Rahme GJ, Israel MA (2015) Id4 suppresses MMP2-mediated invasion of glioblastoma-derived cells by direct inactivation of Twist 1 function. Oncogene 34:53-62 
Roberts EC, Deed RW, Inoue T, Norton JD, Sharrocks AD (2001) Id helix-loop-helix proteins antagonize pax transcription factor activity by inhibiting DNA binding. Mol Cell Biol 21:524-533

Romero-Lanman EE, Pavlovic S, Amlani B, Chin Y, Benezra R (2012) Id1 maintains embryonic stem cell self-renewal by up-regulation of Nanog and repression of Brachyury expression. Stem Cells Dev 21:384-393

Roschger C, Cabrele C (2017) The Id-protein family in developmental and cancer-associated pathways. Cell Commun Signal 15:7

Saisanit S, Sun XH (1997) Regulation of the pro-B-cell-specific enhancer of the Id1 gene involves the C/EBP family of proteins. Mol Cell Biol 17:844-850

Samanta J, Kessler JA (2004) Interactions between ID and OLIG proteins mediate the inhibitory effects of BMP4 on oligodendroglial differentiation. Development 131:4131-4142

Schildge S, Bohrer C, Pfurr S, Mammadzada K, Schachtrup K, Schachtrup C (2014) Instructions from the vascular system - directing neural stem cell fate in health and disease. Curr Med Chem 21:2190-2207

Setten RL, Rossi JJ, Han SP (2019) The current state and future directions of RNAi-based therapeutics. Nat Rev Drug Discovery $18: 421-446$

Soroceanu L, Murase R, Limbad C, Singer E, Allison J, Adrados I, Kawamura R, Pakdel A, Fukuyo Y, Nguyen D, Khan S, Arauz R, Yount GL, Moore DH, Desprez PY, McAllister SD (2013) Id-1 is a key transcriptional regulator of glioblastoma aggressiveness and a novel therapeutic target. Can Res 73:1559-1569

Spillantini MG, Schmidt ML, Lee VM, Trojanowski JQ, Jakes R, Goedert M (1997) Alpha-synuclein in Lewy bodies. Nature 388:839-840

Stiles CD, Rowitch DH (2008) Glioma stem cells: a midterm exam. Neuron 58:832-846

Sullivan JM, Havrda MC, Kettenbach AN, Paolella BR, Zhang Z, Gerber SA, Israel MA (2016) Phosphorylation regulates Id2 degradation and mediates the proliferation of neural precursor cells. Stem Cells 34:1321-1331

Sun XH, Copeland NG, Jenkins NA, Baltimore D (1991) Id proteins Id1 and Id2 selectively inhibit DNA binding by one class of helix-loophelix proteins. Mol Cell Biol 11:5603-5611

Svobodova J, Cabrele C (2006) Stepwise solid-phase synthesis and spontaneous homodimerization of the helix-loop-helix protein Id3. ChemBioChem 7:1164-1168

Tournay O, Benezra R (1996) Transcription of the dominant-negative helix-loop-helix protein Id1 is regulated by a protein complex containing the immediate-early response gene Egr-1. Mol Cell Biol 16:2418-2430

Trausch-Azar JS, Lingbeck J, Ciechanover A, Schwartz AL (2004) Ubiquitin-proteasome-mediated degradation of Id1 is modulated by MyoD. J Biol Chem 279:32614-32619

Tzeng SF, Bresnahan JC, Beattie MS, de Vellis J (2001) Upregulation of the HLH Id gene family in neural progenitors and glial cells of the rat spinal cord following contusion injury. J Neurosci Res 66:1161-1172
Wang S, Sdrulla A, Johnson JE, Yokota Y, Barres BA (2001) A role for the helix-loop-helix protein Id2 in the control of oligodendrocyte development. Neuron 29:603-614

Wojnarowicz PM, Lima ESR, Ohnaka M, Lee SB, Chin Y, Kulukian A, Chang SH, Desai B, Garcia Escolano M, Shah R, Garcia-Cao M, Xu S, Kadam R, Goldgur Y, Miller MA, Ouerfelli O, Yang G, Arakawa T, Albanese SK, Garland WA, Stoller G, Chaudhary J, Norton L, Soni RK, Philip J, Hendrickson RC, Iavarone A, Dannenberg AJ, Chodera JD, Pavletich N, Lasorella A, Campochiaro PA, Benezra R (2019) A small-molecule Pan-Id antagonist inhibits pathologic ocular neovascularization. Cell Rep 29:62-75 e67

Wong MV, Jiang S, Palasingam P, Kolatkar PR (2012) A divalent ion is crucial in the structure and dominant-negative function of ID proteins, a class of helix-loop-helix transcription regulators. PLoS One 7:e48591

Xu M, Nie L, Kim SH, Sun XH (2003) STAT5-induced Id-1 transcription involves recruitment of HDAC1 and deacetylation of C/EBPbeta. EMBO J 22:893-904

Yates PR, Atherton GT, Deed RW, Norton JD, Sharrocks AD (1999) Id helix-loop-helix proteins inhibit nucleoprotein complex formation by the TCF ETS-domain transcription factors. EMBO J 18:968-976

Yi SH, Jo AY, Park CH, Koh HC, Park RH, Suh-Kim H, Shin I, Lee YS, Kim J, Lee SH (2008) Mash1 and neurogenin 2 enhance survival and differentiation of neural precursor cells after transplantation to rat brains via distinct modes of action. Mol Ther 16:1873-1882

Ying QL, Nichols J, Chambers I, Smith A (2003) BMP induction of Id proteins suppresses differentiation and sustains embryonic stem cell self-renewal in collaboration with STAT3. Cell 115:281-292

Yu P, Zhang YP, Shields LB, Zheng Y, Hu X, Hill R, Howard R, Gu Z, Burke DA, Whittemore SR, Xu XM, Shields CB (2011) Inhibitor of DNA binding 2 promotes sensory axonal growth after SCI. Exp Neurol 231:38-44

Yun K, Mantani A, Garel S, Rubenstein J, Israel MA (2004) Id4 regulates neural progenitor proliferation and differentiation in vivo. Development 131:5441-5448

Zhang R, Boareto M, Engler A, Louvi A, Giachino C, Iber D, Taylor V (2019) Id4 downstream of Notch2 maintains neural stem cell quiescence in the adult hippocampus. Cell Rep 28:1485-1498 e1486

Zhou Q, Anderson DJ (2002) The bHLH transcription factors OLIG2 and OLIG1 couple neuronal and glial subtype specification. Cell 109:61-73

Ziv Y, Avidan H, Pluchino S, Martino G, Schwartz M (2006) Synergy between immune cells and adult neural stem/progenitor cells promotes functional recovery from spinal cord injury. Proc Natl Acad Sci U S A 103:13174-13179

Publisher's Note Springer Nature remains neutral with regard to jurisdictional claims in published maps and institutional affiliations. 